Iryna Fedulova, D.Sc., Professor, Kyiv National University of Trade and Economics, Kyiv, Ukraine

Galina Piatnytska, D.Sc., Professor, Kyiv National University of Trade and Economics, Kyiv, Ukraine

Lyudmila Lukashova, Ph.D., Associate Professor, Kyiv National University of Trade and Economics, Kyiv, Ukraine

\title{
SMALL BUSINESS IN UKRAINE: PECULIARITIES AND PROBLEMS OF DEVELOPMENT IN THE CONDITIONS OF THE FOURTH INDUSTRIAL REVOLUTION
}

The goal of the article is to identify peculiarities and main problems of small business development in Ukraine, including taking into account changes in the market environment as a result of the deployment of the fourth industrial revolution. To achieve this goal the following tasks are set: to analyze the specific operation of small businesses along with big and medium; identify trends of small businesses compared with big and medium in Ukraine and small businesses in other countries; to determine the factors influencing the formation of these trends; to assess the level of innovation potential of small enterprises of Ukraine in terms of types of economic activity; identify potential internal strengths and weaknesses, opportunities and threats of small business development in Ukraine. It has been established that in the countries of the European Union (EU), the USA and Japan, small and medium-sized enterprises account for about $50 \%$ of the total number of employed. Their share in GDP is more than $50 \%$. For comparison, the added value of small and medium-sized businesses in Ukraine amounted to 60,1\% in 2016. At the same time, there is a certain difference between Ukraine and the EU countries in the allocation of value added by size of enterprises. So, in the EU micro-enterprises produce more than $20 \%$ of value added, and small and medium-sized enterprises about $18 \%$. In Ukraine, the bulk of value added $(43,4 \%)$ is formed by medium-sized enterprises. The small enterprises is formed $16,7 \%$ of value added, and micro enterprises - only $5,4 \%$, which indicates the low efficiency of micro enterprises in Ukraine. Among the factors that now have a negative impact on the development of small businesses in Ukraine, the following are highlighted: very low demand for products (59\% of 1800 respondents), unstable political situation (44\%); high taxes (35\%); complex tax administration (27\%); inflation and frequent changes in legislation (26\%), high regulatory pressure and corruption (23\%); war in the east of the country (20\%); low availability of loans (19\%). Among other factors, insufficient financial capacity remains a significant obstacle to the expansion and improvement of the activities of small enterprises. Problems with lack of financing for business development are relevant for $44 \%$ of small and medium-sized enterprises. The difficulties of bringing small businesses in foreign markets are another widespread problem. $33 \%$ of medium-sized and $36 \%$ of small enterprises suffer from the lack of working capital. In Ukraine small entrepreneurs also complain about limited opportunities for obtaining loans. The main factor that makes enterprises abandon bank lending are high rates. The most important measures of the state policy to promote the development of small business in conditions of the fourth industrial revolution should be such as: reducing the number of documents required for business, simplifying tax administration and transforming the State fiscal service into a service for taxpayers, creating a single information resource for entrepreneurs and transfer of administrative services to electronic mode, improvement of credit conditions.

Keywords: small enterprises; small and medium businesses; entrepreneurship; internal strengths and weaknesses of development; external opportunities and threats; innovative potential; the Fourth Industrial Revolution; scientific and technical progress. 
Problem statement in general form. Studying the theory and practice of small businesses in Ukraine would enable you to identify main problems that hinder the development of small and medium businesses, and provide practical recommendations for optimizing and improving efficiency. These issues are becoming especially important during the formation of the concept of the Fourth Industrial Revolution. Since the latest predictions, the proliferation of artificial intelligence would release many jobs. Issues related to the creation of the right conditions for the development of small business (including microenterprises) require particular attention for the implementation of the tasks of overcoming unemployment, the development of personality and material security of man.

Recent research and publications analysis. The experience of implementing an effective mechanism for the functioning of small business in their countries was considered by many scholars. Thus, Bartoš, P., Rahman, A., Horák, J., Jáčová, H. [1] were considering how small business owners in the Czech Republic perceive the role of the state. This perception differs according to their level of education. Samitowska, W. [2] studied the most serious obstacles for business management with which small business entrepreneurs in Poland face. The crucial role of the state and local self-government among the factors of small business development was determined. The study by Civelek, M., Ključnikov, A., Dobrovič, J., Hudáková, M. [3] showed that in the segment of small and medium business the most important is the definition of qualitative and quantitative characteristics of the business environment at the state level in general and in particular regions.

Studies of the state of small business development in Ukraine were conducted by such scholars as Georgiadi G. [4], Melen O.V., Abramova O.V. [5], Simkov L.Ye., Pobigun S.A. [6], Tabinsky V.A., Telyatnik V.M., Simon A.P. [7], Timchenko O.I. [8], Feshchenko S.S. [9] and many others. Their research identifies the main trends, problems and prospects of small business development in Ukraine.

Some scientists, in particular: Apostolyuk O.Yu. [10], Varnalia Z.S. [11], Polishchuk G.O. [12] and many others, emphasized their scientific research on the issues of state support for the functioning of the small business. These studies generalized the existing state of governmental regulation of small business in Ukraine and identified some issues of using foreign experience on this issue in Ukrainian realities.

Some problematic aspects of management of economic activity of small entrepreneurs, evaluation of the innovative potential of small enterprises, determination of strategic prospects for their development were also the subject of our previous research [13; 14 and others.].

27 meetings were devoted to the problems of the formation of the 4 industrial revolutions at the World Economic Forum in Davos in 2017. K. Schwab [15], addressing here, has determined that the era of innovation begins when advanced technologies significantly change the entire economy and develop at very fast pace. S.M. Illyashenko, N.S. Ilyashenko [16] outlined the problems and threats of the Fourth Industrial Revolution in Ukraine and their influence on the strategic development of enterprises. The development of small and medium businesses is acquiring particular importance here, as more flexible, dynamic and peculiar to rapid adaptation.

Outlining previously unsettled parts of the general problem. Nevertheless, most of the abovementioned publications are rather generalized or fragmentary. The theoretical and practical recommendations outlined in them, need to be detailed to the level of theoretical and methodological developments, which must be aimed at the planning of concrete measures on support, motivation, development, investment and innovation activity of small business in Ukraine with the definition of their priority. In addition, the concept of the 4th Industrial Revolution envisages taking into account its main principles and objectives in the prediction of the directions of development of small business in the country.

The aims of the article are the identification of peculiarities and main problems of small business development in Ukraine, including changes in the market environment as a result of the deployment of the Fourth Industrial Revolution. To achieve this goal, tasks are as follows: to analyze the specifics of the functioning of small enterprises, along with large and medium ones; to identify the trends of small business 
development in comparison with large and medium enterprises in Ukraine and small business in other countries of the world; to determine the factors influencing the formation of these trends; to conduct an assessment of the level of innovation potential of small enterprises of Ukraine in terms of types of economic activity; identify potential internal strengths and weaknesses, opportunities and threats of small business development in Ukraine. To accomplish the tasks, the following scientific methods will be used: system analysis; statistical data processing; comparisons; SWOT analysis, etc.

Research results. In the economy of developed countries, large, medium and small enterprises simultaneously operate, as well as activities based on personal and family labour. The modern economy is characterized by a complex combination of different in scale of productions. On the one hand, these are large enterprises with significant capacities and scale effects, and on the other hand, small enterprises that derive their benefits from activities in individual segments and meet the needs of a particular consumer.

Modern trends in the development of scientific and technological progress cause trends in production concentration. Large enterprises have considerable material, financial, labour and intellectual resources. They are capable of conducting large-scale scientific and technological developments, which determine technological progress. This allows large enterprises to compete successfully both at the price and at the speed of meeting the customer's qualitative needs. But at the same time, there are also tendencies of growth of enterprises of small and medium business, especially in the areas where it does not yet require significant capital, large volumes of equipment and cooperation of many workers.

With the proliferation of digital technologies, humanity is waiting for the transition from the competition of products and services to competition for measurable results and value for customers, or the so-called Outcome economy. Nowadays, efficiency will depend not on the cost of products and services, but on the results that the consumer will achieve, and the values that they will represent to him.

This, in turn, may necessitate the growth of small and medium enterprises. Experience has shown that today small and medium enterprises are especially well-versed in high-tech types of production, as well as in the sectors related to the production of consumer goods and services.

In order for a small business to absorb the necessary number of people who will be released due to the proliferation of artificial intelligence - it is preferable that the business climate in the country was favourable for self-economic activity. Otherwise, a person will expect from the state appropriate and longterm care. The prediction of the total number of people who will lose jobs by 2050, in turn, suggests that this may become an important task of ensuring the country's social and economic stability.

A stable development of Ukrainian economic system is impossible without taking into account some changes in the small sector of the economy. Today, there are several socio-economic problems that our state is facing with: filling the market with the goods and services that consumers want to see, creating new jobs, creating an effective competitive environment, filling the budget and stable economic development. Solving all these problems can provide if not entirely, in part, assistance in the development of small business, The experience of most developed countries of the world convincingly proves the necessity of existence and ensuring effective activity of the small business

Effective functioning of small forms of production under certain conditions of management is determined by their advantages in comparison with large production: proximity to local markets and adaptation to consumer inquiries; small batch production, unprofitable for large enterprises; the exclusion of extra control units and more. The small-scale production is facilitated by the differentiation and individualization of demand, which today have a decisive importance in the field of industrial and personal consumption.

All small and medium enterprises can be divided into two groups. The first group is an enterprise that directly or indirectly relates to a large business. Remaining legally independent, they work on a contract with large enterprises. This group of enterprises has its own characteristic: specialization in the production 
of a limited range of products (which deprives large enterprises of the diversion of limited resources for its production in their workshops); lower production costs, allowing large businesses to save their resources; the flexibility of production, which contributes to its rapid conversion, replacement models, product upgrades. Finally, small business enterprises are in the new stage of scientific and technological progress, on the one hand, as experimenters for large firms, and on the other - as firms serving new products created by large enterprises.

The second group includes small businesses, which compete directly with large and medium businesses and among themselves on the market. The prerequisites for the development of this group of companies are: the ability to respond quickly to market demands and meet the emerging demand for goods and services; significantly smaller start-up capital, which allows it to manoeuvre more freely than its more powerful competitors; the desire to fill the compartment, which for various reasons is not advantageous for large enterprises; and finally, the price policy of large firms that dictate the market quite high prices.

There were over 1.8 million small and medium businesses in Ukraine in 2016, despite the tendency to decrease (especially in recent times) the number of both the first and the others (Table 1).

Table 1 - Dynamics of the number of different enterprises varying in size-legal and physical entities-entrepreneurs in Ukraine during 2010-2016 (calculated by the authors according to the data of the State Statistics Service of Ukraine [17])

\begin{tabular}{|l|c|c|c|c|c|}
\hline \multirow{2}{*}{ Years } & \multicolumn{3}{|c|}{ Legal entities } & \multicolumn{2}{c|}{ Physical entities } \\
\cline { 2 - 6 } & Large & Medium & Small & $\begin{array}{c}\text { Entities of } \\
\text { medium business }\end{array}$ & $\begin{array}{c}\text { Entities of } \\
\text { small business }\end{array}$ \\
\hline 2010 & 586 & 20983 & 357241 & 355 & 1804763 \\
\hline 2011 & 659 & 20753 & 354283 & 306 & 1325619 \\
\hline 2012 & 698 & 20189 & 344048 & 361 & 1234831 \\
\hline 2013 & 659 & 18859 & 373809 & 351 & 1328392 \\
\hline 2014 & 497 & 15906 & 324598 & 712 & 1590448 \\
\hline 2015 average absolute & 423 & 15203 & 327814 & 307 & 1630571 \\
\hline 2016 - & -383 & 14832 & 291154 & 281 & 1558880 \\
\hline $\begin{array}{l}\text { Annual } \\
\text { increase / decrease }\end{array}$ & -1025 & -11015 & -12 & -40981 \\
\hline $\begin{array}{l}\text { Annual compound rate of increase } \\
\text { / decrease, \% }\end{array}$ & $-6,8$ & $-5,6$ & $-3,4$ & $-3,8$ & $-2,4$ \\
\hline Basic temp of increase $(2016 / 2010), \%$ & $-34,6$ & $-29,3$ & $-18,5$ & $-20,8$ & $-13,6$ \\
\hline Basic temp of growth $(2016 / 2010), \%$ & 65,4 & 70,7 & 81,5 & 79,2 & 86,4 \\
\hline
\end{tabular}

The share of small enterprises in 2016 represented $95 \%$, while the average $-4.9 \%$ of the total number of legal entities. The lion's share of small enterprises in 2016 functioned as a microenterprise $-80.8 \%$ (Table 2).

Table 2 - Change of the structure of Ukrainian enterprises by their size during $2010-2016, \%$ (17)

\begin{tabular}{|c|c|c|c|c|}
\hline \multirow{2}{*}{ Years } & \multirow{2}{*}{$\begin{array}{c}\text { Large } \\
\text { enterprises }\end{array}$} & \multirow{2}{*}{$\begin{array}{c}\text { Medium } \\
\text { enterprises }\end{array}$} & \multicolumn{2}{|c|}{ Small enterprises } \\
\hline & & & Total & Among them microenterprises \\
\hline 2010 & 0,2 & 5,5 & 94,3 & 79,3 \\
\hline 2011 & 0,2 & 5,5 & 94,3 & 78,7 \\
\hline 2012 & 0,2 & 5,5 & 94,3 & 78,5 \\
\hline 2013 & 0,2 & 4,8 & 95,0 & 81,0 \\
\hline 2014 & 0,1 & 4,7 & 95,2 & 81,8 \\
\hline 2015 & 0,1 & 4,4 & 95,5 & 82,8 \\
\hline 2016 & 0,1 & 4,9 & 95,0 & 80,8 \\
\hline Average & 0,15 & 5,04 & 94,80 & 80,41 \\
\hline
\end{tabular}


Data for 2010-2016 indicate a negative dynamics of the development of business entities in the country. Thus, the number of large legal entities for the study period decreased annually by an average of 34 enterprises (or 6.8\%); the average, respectively, 1025 enterprises (or 5.6\%), small enterprises, respectively, 11015 (or 9.7\%). Individuals related to medium and small businesses also showed a downward trend, but their average annual rate of decline was $3.8 \%$ and $2.4 \%$ respectively, which is lower than the same figure among legal entities.

Small business plays an important role in the development of the economy of many countries. In the countries of the European Community (EU), in the USA and Japan, small and medium enterprises account for about $50 \%$ of the total number of employed. Their share in GDP is more than $50 \%$. In turn, the added value of small and medium businesses in Ukraine in 2016 represented $60.1 \%$. At the same time, there is a certain difference between Ukraine and the EU countries in the allocation of value added by size of enterprises. So, in the EU micro-enterprises produce more than $20 \%$ of value added, and small and medium-sized enterprises - about $18 \%$. In Ukraine, the bulk of value added (43.4\%) is formed by medium enterprises. At a low rate of $16.7 \%$, and a microenterprise - only $5.4 \%$, which indicates the low efficiency of microenterprises [17; 18].

According to the results of 2016, the volume of sales (goods, services) of small and medium businesses amounted to $61.7 \%$ of the total volume (58.4\% in 2010) (Figure. 1).

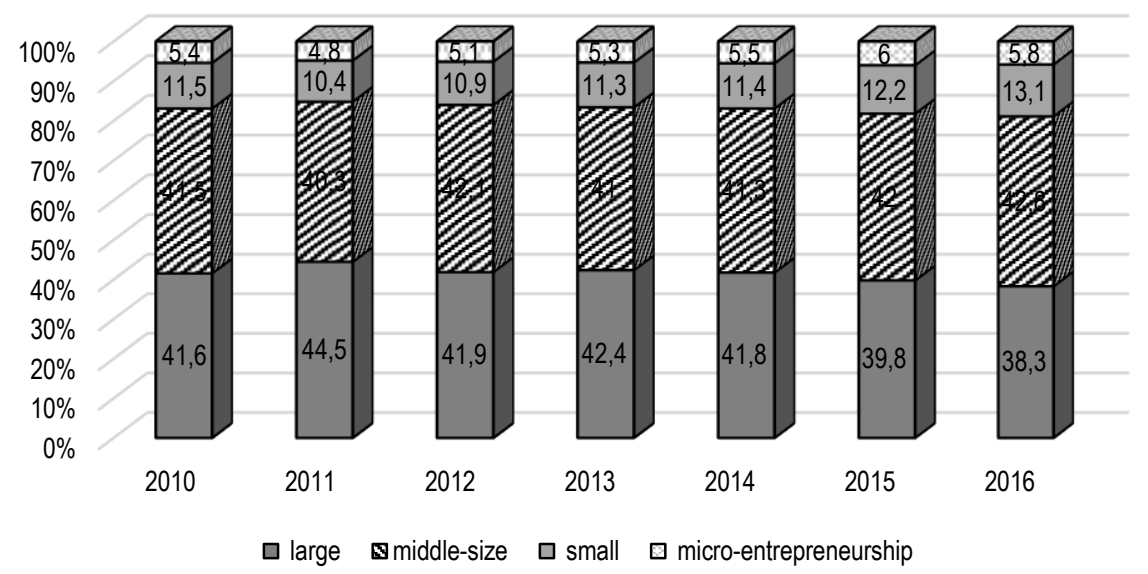

\section{Figure 1 - Share of sales volumes (goods, services) by large, medium, small and micro enterprises in Ukraine during 2010-2016, \% (17)}

At the same time, medium enterprises in 2016 accounted for $42.8 \%$ of sales volumes, at the smallest $-13.1 \%$, and for microenterprises $-5.8 \%$ (Figure 1). This indicator is comparable to European countries. Thus, in Germany, the share of small and medium-sized enterprises in the total volume of sales in 2015 was 47.5\%, in Poland - 56\%, in the Czech Republic - 56.9\%, Lithuania - 68.5\%, Latvia - 77.8\% [17; 18].

The dynamics of sales of goods (goods and services) in \% by 2010 shows a similar tendency for all enterprises, but small and medium businesses show somehow better dynamics than big business. Thus, in 2016, in relation to 2010, the growth rate of sales (goods and services) for large enterprises represented $116.5 \%$, and for medium, small and micro enterprises, respectively, 123.1; 129.5 and 117.7\% (Figure 2).

Recently, there are crises in Ukraine, that are characterized primarily by inflationary processes and fluctuations in hryvnia (UAH), that is why it is important to analyze the performance of enterprises both in 
hryvnias (UAH) and in dollar equivalent per enterprise. This will allow us to determine the actual trend of the total value indicator. In 2016, one large enterprise averaged 6244,01 million UAH. or 244371 thousand dollars, respectively, for one average - 179.93 million UAH. or 7041,8 thousand dollars, and on small 4,04 million UAH. or 158,3 thousand dollars (Table 3).

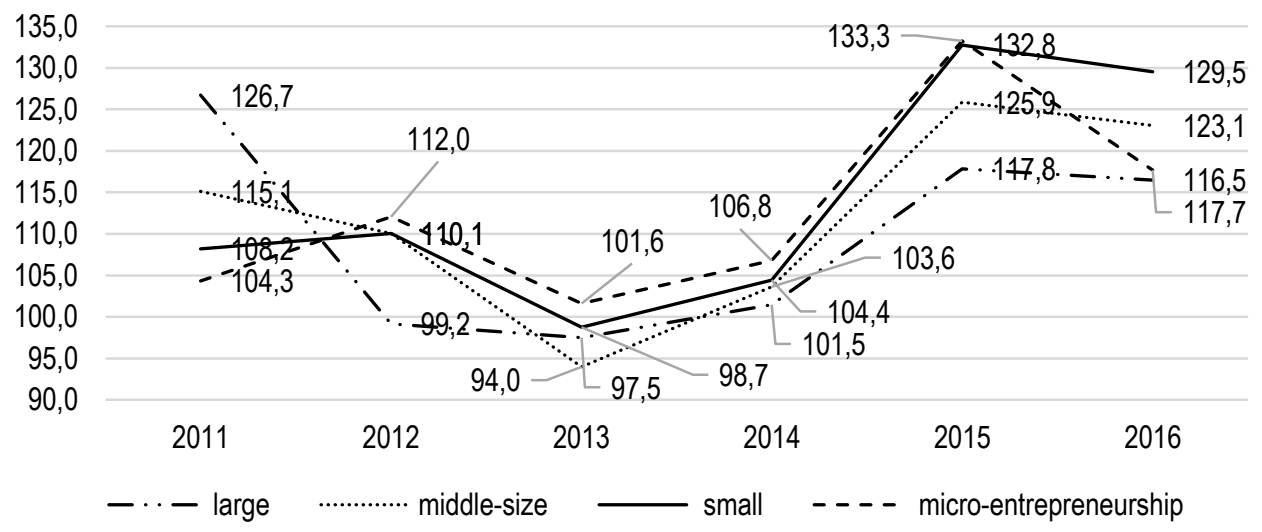

Figure 2 - Dynamics of sales volumes (goods, services) by large, medium, small and micro enterprises, $\%$ by 2010 (17)

Table 3 - Dynamics of sales volumes per one business entity in terms of the size of legal entities of Ukraine during 2010-2016 (18)

\begin{tabular}{|c|c|c|c|c|c|c|c|c|}
\hline \multirow{2}{*}{ Years } & \multicolumn{2}{|c|}{ Large enterprises } & \multicolumn{2}{|c|}{ Medium enterprises } & \multicolumn{2}{|c|}{ Small enterprises } & \multicolumn{2}{|c|}{ Microenterprises } \\
\hline & $\begin{array}{c}\text { Million } \\
\text { UAH }\end{array}$ & $\begin{array}{l}\text { Thousand } \\
\text { dollars (\$) }\end{array}$ & $\begin{array}{c}\text { Million } \\
\text { UAH }\end{array}$ & $\begin{array}{l}\text { Thousand } \\
\text { dollars (\$) }\end{array}$ & $\begin{array}{c}\text { Million } \\
\text { UAH }\end{array}$ & $\begin{array}{l}\text { Thousand } \\
\text { dollars (\$) }\end{array}$ & $\begin{array}{c}\text { Million } \\
\text { UAH }\end{array}$ & $\begin{array}{l}\text { Thousand } \\
\text { dollars (\$) }\end{array}$ \\
\hline 2010 & 2391,8 & 301400,2 & 66,5 & 8385,9 & 1,6 & 200,5 & 0,6 & 76,3 \\
\hline 2011 & 2694,7 & 338213,0 & 77,5 & 9722,5 & 1,7 & 215,3 & 0,6 & 80,5 \\
\hline 2012 & 2523,0 & 315734,8 & 87,6 & 10967,7 & 2,0 & 244,7 & 0,7 & 92,9 \\
\hline 2013 & 2606,1 & 326042,4 & 88,2 & 11029,4 & 1,8 & 224,3 & 0,7 & 84,9 \\
\hline 2014 & 3506,1 & 294956,9 & 108,3 & 9113,9 & 2,2 & 182,7 & 0,8 & 69,6 \\
\hline 2015 & 4853,9 & 222199,3 & 142,7 & 6530,4 & 2,9 & 130,9 & 1,1 & 49,5 \\
\hline 2016 & 6244,0 & 244371,0 & 179,9 & 7041,8 & 4,0 & 158,3 & 1,5 & 57,2 \\
\hline
\end{tabular}

If we look at the dynamics of the indicator of sales (goods and services) in dollar terms, then it differs from the general dynamics of this indicator in UAH. In enterprises of all sizes, the volume of sales (goods, services) to one enterprise in thousands of dollars shows a drop from 2012-2013 up to 2015, and only in 2016 , there is a slight increase. However, even in 2016, the value of this indicator has not yet reached the level of 2010.

An important task for small businesses is the employment of the population, which in turn affects the level of income, purchasing power and the level of satisfaction with labour. The state should stimulate small business for development and provide favourable conditions for economic activity.

The statistics show that about $80 \%$ of the total number of employed in the economy works in medium and small enterprises in Ukraine. But the wages of different enterprises vary greatly. If at large enterprises the average monthly salary per one employed in 2016 represented more than 7.5 thousand $\mathrm{UAH}$, then in medium enterprises - 5 thousand $\mathrm{UAH}$, in small ones - only 1,239 thousand $\mathrm{UAH}$, and in microenterprises in general $-513,1 \mathrm{UAH}$ [17]. This can be explained, in particular, by the fact that wages are paid officially 
at large enterprises, and on average and small ones - mostly in the envelope, although the real salary of small and medium enterprises may be lower.

In Ukraine, one large enterprise in 2016 employed an average of 4143 people, on average - 179, in small ones - 89, and micro enterprises - 11 people. In the last 7 years, this trend has not changed significantly. The results of our analysis showed that the share of employed workers in their total number in 2016 at small enterprises amounted to $47.8 \%$ (46\% in 2010), the average $-32.7 \%$ (31.7\% in 2010). ) and large $-19,6 \%(22,3 \%$ in 2010$)[17]$.

The volume of sales per one employee in large enterprises of Ukraine is about three times larger than the same indicator at small enterprises and is 1.5 times higher than the average. However, all enterprises show a positive dynamics of growth of this indicator for the period under study. Thus, from 2010 to 2016, this indicator at large enterprises increased by 2,08 times, on average by 2,05 times, and by small ones by 2,35 times [17].

The size of enterprises depends on the specifics of industries and their technological features. There are industries that are associated with high capital intensity and significant volumes of production and industries that do not require large enterprises, but on the contrary, the small ones are the best.

An essential part of small businesses specializes in trade: as of the end of 2016 , presented $27.3 \%$ of the total number of small enterprises in Ukraine. Almost two times less, namely $14.6 \%$ of small enterprises in 2016 engaged in activities in the field of agriculture, forestry and fisheries. The share of small industrial enterprises was even lower $-11.6 \%$, construction - $8.1 \%$, professional scientific and technical activities $8.3 \%$, real estate transactions were handled by $10 \%$ of small enterprises relative to their total number in Ukraine (Table. 4).

Table 4 - Shares of large, medium, small and micro enterprises by types of economic activity in their total number in 2010 and 2016 (17)

\begin{tabular}{|c|c|c|c|c|c|}
\hline \multirow{2}{*}{$\begin{array}{l}\text { Enterprises by types of economic } \\
\text { activity }\end{array}$} & \multirow{2}{*}{ Years } & \multicolumn{3}{|c|}{ Enterprises } & \multirow{2}{*}{ Microenterprises } \\
\hline & & Large & Medium & Small & \\
\hline 1 & 2 & 3 & 4 & 5 & 6 \\
\hline \multirow{2}{*}{ Total } & 2010 & 100 & 100 & 100 & 100 \\
\hline & 2016 & 100 & 100 & 100 & 100 \\
\hline \multirow{2}{*}{$\begin{array}{l}\text { Agriculture, fisheries and forest } \\
\text { management }\end{array}$} & 2010 & 2,2 & 16,4 & 13,2 & 14,3 \\
\hline & 2016 & 5,2 & 16,9 & 14,6 & 15,1 \\
\hline \multirow{2}{*}{ Industry } & 2010 & 59,2 & 29,1 & 11,6 & 10,2 \\
\hline & 2016 & 54,3 & 31,4 & 11,6 & 10,1 \\
\hline \multirow{2}{*}{ Building construction } & 2010 & 1,7 & 7,1 & 10,3 & 10,2 \\
\hline & 2016 & 0,5 & 5,2 & 8,1 & 7,9 \\
\hline \multirow{2}{*}{$\begin{array}{l}\text { Wholesale and retail trade; repair of } \\
\text { vehicles and motorcycles }\end{array}$} & 2010 & 26,3 & 19,5 & 29,6 & 30,3 \\
\hline & 2016 & 30,3 & 17,8 & 27,3 & 28,0 \\
\hline \multirow{2}{*}{$\begin{array}{l}\text { Transport, warehousing, postal and } \\
\text { courier activities }\end{array}$} & 2010 & 5,6 & 5,9 & 3,5 & 3,1 \\
\hline & 2016 & 5,5 & 7,4 & 4,3 & 4,0 \\
\hline \multirow{2}{*}{$\begin{array}{l}\text { Accommodation and food service } \\
\text { activities }\end{array}$} & 2010 & 0,5 & 2,0 & 2,6 & 2,5 \\
\hline & 2016 & 0,3 & 1,6 & 2,2 & 2,1 \\
\hline \multirow{2}{*}{ Information and telecommunications } & 2010 & 1,5 & 1,9 & 3,6 & 3,6 \\
\hline & 2016 & 1,6 & 2,2 & 4,0 & 4,0 \\
\hline \multirow{2}{*}{ Financial and insurance activity } & 2010 & 1,2 & 2,1 & 1,5 & 1,5 \\
\hline & 2016 & 0,3 & 1,7 & 1,2 & 1,2 \\
\hline \multirow{2}{*}{ Real estate trading } & 2010 & 0,2 & 3,5 & 7,5 & 7,7 \\
\hline & 2016 & 0,5 & 2,9 & 10,5 & 11,2 \\
\hline \multirow{2}{*}{$\begin{array}{l}\text { Professional, scientific and technical } \\
\text { work }\end{array}$} & 2010 & 0,9 & 4,5 & 8,7 & 9,2 \\
\hline & 2016 & 0,5 & 3,7 & 8,3 & 8,9 \\
\hline \multirow{2}{*}{$\begin{array}{l}\text { Work in the field of Administrative and } \\
\text { Support Services }\end{array}$} & 2010 & 0,2 & 5,0 & 4,2 & 3,9 \\
\hline & 2016 & 0,5 & 5,9 & 4,4 & 4,2 \\
\hline
\end{tabular}


Table 4

\begin{tabular}{|l|c|c|c|c|c|}
\hline \multicolumn{1}{|c|}{1} & 2 & 3 & 4 & 5 & 6 \\
\hline \multirow{2}{*}{ Education } & 2010 & 0,2 & 0,5 & 0,7 & 0,6 \\
\cline { 2 - 6 } & 2016 & - & 0,4 & 0,6 & 0,6 \\
\hline \multirow{2}{*}{ Health-care and social support } & 2010 & - & 1,4 & 1,2 & 1,1 \\
\cline { 2 - 6 } & 2016 & - & 1,9 & 1,3 & 1,0 \\
\hline \multirow{2}{*}{$\begin{array}{l}\text { Art, sport, entertainment and } \\
\text { recreation }\end{array}$} & 2010 & 0,3 & 0,5 & 0,6 & 0,6 \\
\hline \multirow{2}{*}{\begin{tabular}{l} 
Provision of other services \\
\cline { 2 - 6 }
\end{tabular}} & 2016 & 0,5 & 0,8 & 0,5 & 0,5 \\
\cline { 2 - 6 } & 2010 & - & 0,4 & 1,3 & 1,2 \\
\hline
\end{tabular}

The identification of factors that characterize the internal strengths and weaknesses of this business, as well as external opportunities and threats to its sustainable is important in terms of developing sound strategies for small business development in the 4th Industrial Revolution.

The Union of Ukrainian Entrepreneurs (SMU) conducted a study of the mood of small and medium businesses [18]. According to the survey, $67 \%$ of small and medium enterprises in Ukraine expanded in 2017, despite the continuation of the crisis in the country's economy. In 2018, most respondents predict business growth. First of all, due to increased sales (89.7\%) and the opening of a new business (39.7\%). $75 \%$ of respondents intend to increase the number of employees, and half of the respondents predict next year to enter new markets. None of the respondents plans to reduce their business in 2018. Such results show that, despite all the obstacles, small and medium businesses in Ukraine have the potential and aspiration for development.

The results of the above-mentioned survey allowed to identify a number of factors that hinder the development of small businesses. $26 \%$ of respondents indicated that their growth was restrained by pressure from law enforcement agencies. In 2017, 14\% of businessmen searched and blocked the company's law enforcement. The main constraining factor for business development for Ukrainian entrepreneurs is the lack of skilled personnel - $32 \%$ of respondents. Equally critical for business is limited access to resources and high tax burden. Also, the top 8 issues for business include excessive regulation of export activity and the economy as a whole, corruption in controlling bodies and military actions in the country [18].

The largest contribution of small and medium businesses to the Ukrainian economy is realized by companies that introduce innovative products and technologies. The research showed that over the past 2 years, $32 \%$ of enterprises have been producing new products or implementing new services, $22 \%$ have introduced new processes in production or provision of services, $18 \%$ - new methods of promotion and marketing of goods, $16 \%$ - new methods of enterprise management. Small business markets were distributed as follows: $51 \%$ - local market, $42 \%$ - regional market, $36 \%$ - all-Ukrainian market, $20 \%$ neighbouring markets, $6 \%$ - EU market, $8 \%$ - other international markets [19].

At the same time, it have to be noted that, unfortunately, the majority of small enterprises of Ukraine, at the end of 2016 had a low level of innovation potential by sources of expenses (Table 5), which created certain obstacles for the painless adaptation of these enterprises to the realities of activity in conditions of distribution of the 4th Industrial Revolution. The most promising on this issue today is small enterprises of agriculture, forestry and fisheries, and those engaged in financial and insurance activities, that is those in which the level of innovative potential is medium and high, respectively.

The survey of small and medium businesses, conducted annually within the framework of the USAID Leadership in Economic Management program and covering over 1,800 respondents, has shown that among the factors that negatively affected business development in 2016, the lack of demand for small and medium enterprises medium-sized enterprises ( $59 \%$ of respondents), in the second place an unstable political situation ( $44 \%$ of respondents indicated it). $35 \%$ of business representatives complained about 
I. Fedulova, G. Piatnytska, L. Lukashova. Small Business of Ukraine: Peculiarities and Problems of Development in the Conditions of the Fourth Industrial Revolution

high taxes (for taxes in 2016, small and medium and companies spent an average of $24.9 \%$ of their income); complex tax administration - 27\%; inflation and frequent changes in economic legislation - $26 \%$; high regulatory pressure and corruption as barriers; $23 \%$ of those polled, the East War, $20 \%$. Low availability of loans and high rates were determined by $19 \%$ and $17 \%$, respectively, of representatives of small and medium enterprises (Figure 3).

Table 5 - Level of innovative potential of small enterprises of Ukraine according to the sources of expenses by the types of economic activity at the end of 2016, UAH million (calculated by the authors according to the data of the State Statistics Service of Ukraine 17, p. 145-146, 149-150, 157$158,163-164,169-170,179-180)$

\begin{tabular}{|c|c|c|c|c|c|c|c|}
\hline \multirow{2}{*}{$\begin{array}{l}\text { Small enterprises by } \\
\text { types of economic } \\
\text { activity }\end{array}$} & \multirow{2}{*}{$\begin{array}{l}\text { Equity } \\
\text { working } \\
\text { capital } \\
\text { (EWC) }\end{array}$} & \multirow{2}{*}{$\begin{array}{l}\text { Long-term } \\
\text { loans } \\
\text { (LTL) }\end{array}$} & \multirow{2}{*}{$\begin{array}{l}\text { Short-term } \\
\text { loans } \\
\text { (STL) }\end{array}$} & \multicolumn{3}{|c|}{ Excess $(+)$ or lack (-) to cover expenses } & \multirow{2}{*}{$\begin{array}{l}\text { Level of } \\
\text { innovation } \\
\text { potential }\end{array}$} \\
\hline & & & & EWC & $E W C+L T L$ & $\begin{array}{l}\text { EWC }+ \\
\mathrm{LTL}+\mathrm{STL}\end{array}$ & \\
\hline Total & $-535739,2$ & 451466,8 & 2428018,5 & $-831083,5$ & $-379616,7$ & 2048401,8 & low \\
\hline $\begin{array}{lr}\text { Agriculture, } & \text { fisheries } \\
\text { and } & \text { forest } \\
\text { management } & \end{array}$ & 55517,2 & 17975,1 & 792482,6 & $-9249,5$ & 8725,6 & 801208,2 & middle \\
\hline Industry & $-61838,3$ & 40127,7 & 141730,2 & $-98964,9$ & $-58837,2$ & 82893,0 & low \\
\hline Building construction & $-81348,8$ & 67844,0 & 124111,9 & $-112119,1$ & $-44275,1$ & 79836,8 & low \\
\hline $\begin{array}{l}\text { Wholesale and retail } \\
\text { trade; repair } \begin{array}{r}\text { of } \\
\text { vehicles }\end{array} \\
\text { motorcycles }\end{array}$ & $-108449,9$ & 64029,8 & 668490,1 & $-229093,9$ & $-165064,1$ & 503426,0 & low \\
\hline $\begin{array}{l}\text { Transport, } \\
\text { warehousing, postal } \\
\text { and courier activities }\end{array}$ & $-27146,0$ & 11130,9 & 130584,1 & $-32657,0$ & $-21526,1$ & 109058,0 & low \\
\hline $\begin{array}{l}\text { Accommodation and } \\
\text { food service activities }\end{array}$ & $-9167,1$ & 5938,7 & 8976,6 & $-11062,3$ & $-5123,6$ & 3853,0 & low \\
\hline $\begin{array}{l}\text { Information and } \\
\text { telecommunications }\end{array}$ & $-6959,1$ & 7651,8 & 39856,2 & $-9568,7$ & $-1916,9$ & 37939,3 & low \\
\hline $\begin{array}{l}\text { Financial and } \\
\text { insurance activity }\end{array}$ & 21469,9 & 29739,4 & 70920,8 & 20225,2 & 49964,6 & 120885,4 & low \\
\hline Real estate trading & $-217980,0$ & 141872,5 & 262237,8 & $-235495,9$ & $-93623,4$ & 168614,4 & low \\
\hline $\begin{array}{l}\text { Professional, scientific } \\
\text { and technical work }\end{array}$ & $-70608,9$ & 41182,6 & 124700,4 & $-79093,7$ & $-37911,1$ & 86789,3 & low \\
\hline $\begin{array}{l}\text { Work in the field of } \\
\text { Administrative and } \\
\text { Support Services }\end{array}$ & $-18914,9$ & 18094,7 & 53753,4 & $-21922,5$ & $-3827,8$ & 49925,6 & low \\
\hline Education & $-99,7$ & 55,1 & 570,2 & $-170,7$ & $-115,6$ & 454,6 & low \\
\hline $\begin{array}{l}\text { Health-care and social } \\
\text { support }\end{array}$ & $-1428,2$ & 1279,0 & 1965,3 & $-1843,5$ & $-564,5$ & 1400,8 & low \\
\hline $\begin{array}{lr}\begin{array}{l}\text { Art, } \\
\text { entertainment } \\
\text { recreation }\end{array} & \text { sport, } \\
\text { and }\end{array}$ & $-7584,7$ & 4159,7 & 6219,4 & $-8509,4$ & $-4349,7$ & 1869,7 & low \\
\hline $\begin{array}{l}\text { Provision of other } \\
\text { services }\end{array}$ & $-1200,7$ & 385,8 & 2834,4 & $-1557,6$ & $-1171,8$ & 1662,6 & low \\
\hline
\end{tabular}

Analyzing the respondents' answers to the necessary changes, one can conclude that the representatives of small and medium businesses expect the state not so much direct financial support as creating favourable conditions for development (77\% of respondents). Among the necessary measures to improve the business climate, business representatives often refer to deregulation and simplification of 
tax administration (more than $80 \%$ of respondents). In addition, for $78 \%$ of respondents, it is relevant to create a single information resource, where you can learn about business conditions and changes in legislation. It was also important to support equal business conditions for all business entities regardless of the type of activity ( $74 \%$ of respondents). Most respondents ( $67 \%$ of respondents) consider it necessary to reform the tax service and turn it into a service for taxpayers, while $65 \%$ expect the transfer of administrative services to electronic format [19].

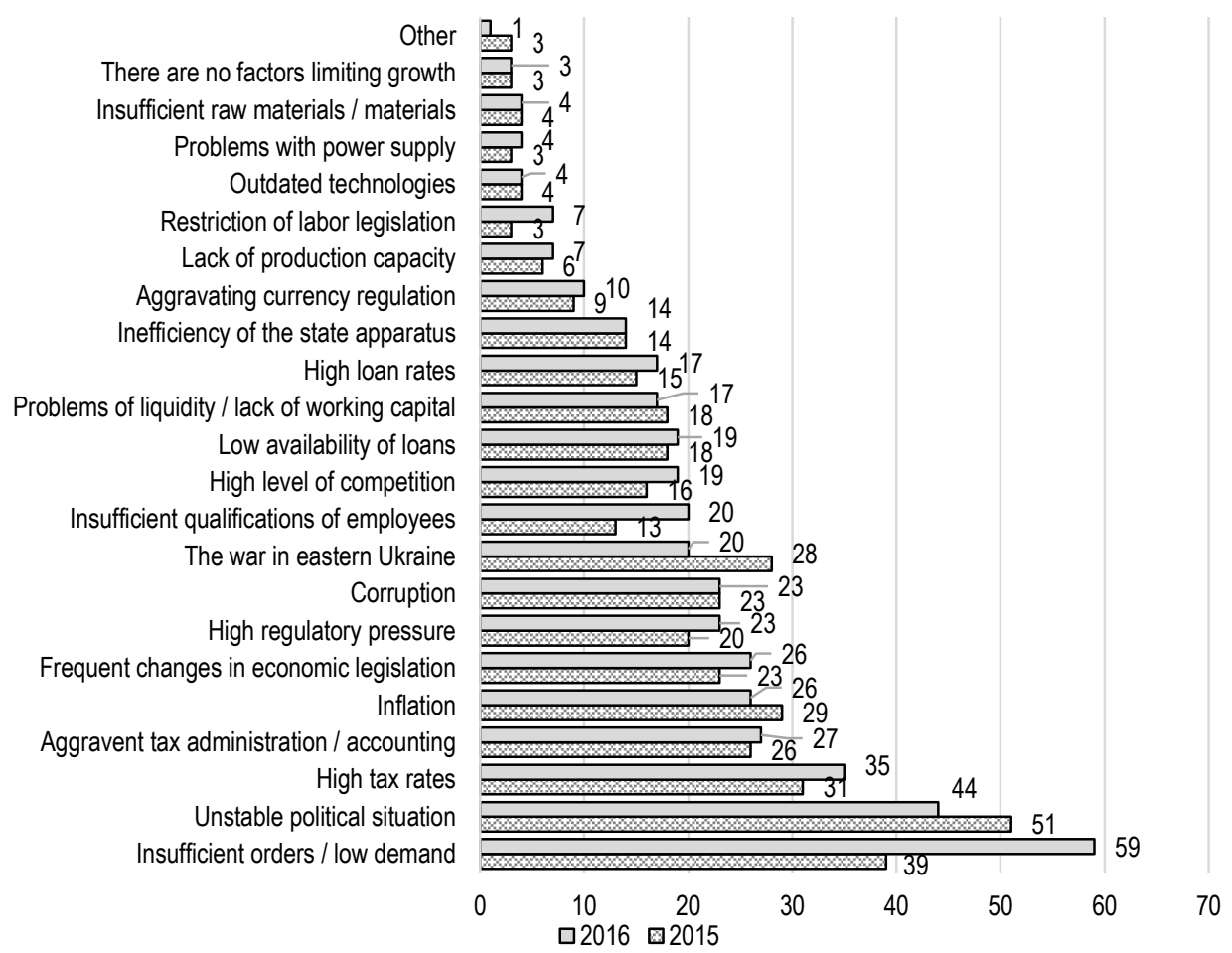

Figure 3 - Threats that hinder the development of small and medium businesses in Ukraine according to the survey as part of a programme USAID Leadership in Economic Management [19]

Among other factors, insufficient financial capacity remains a significant obstacle to the expansion and improvement of the activities of small enterprises. Problems with lack of financing for business development are relevant for $44 \%$ of small and medium businesses. It is also the most widespread problem, which constrains the output of enterprises to foreign markets ( $26 \%$ of respondents) [19].

The availability of loans is a critical condition for the adequacy of financing for entrepreneurship, especially this problem is important for small businesses. Entrepreneurs who work in small businesses find it hard to give certain guarantees to banks, in unfavourable conditions they risk their own property, and the interest on a loan can become an unbearable burden for conducting an efficient business. In addition, small businesses tend to be on the stage of becoming and are eager to develop the already started business, and at this stage, the revenues are insignificant, and the investment needs are high. It is precise because of this that lending conditions are a significant motivating factor for such activities.

The National Bank of Ukraine has released the data of the report "Survey on the conditions of lending" based on the results of a survey of credit managers of 65 banks of Ukraine, the formation of which was 
aimed at deepening understanding of the state and trends of the development of the credit market for lending to small and medium enterprises. $72 \%$ of polled bankers believe that corporate lending will increase over $2018,67 \%$ of respondents predict an increase in lending to households - this is the maximum since the survey began in 2015. In the 4th quarter of 2017, the share of bank approvals for loans to small and medium enterprises increased markedly [20]. According to respondents, the main reason for this is lowering credit rates.

Based on the results of the survey, $33 \%$ of the average and $36 \%$ of small enterprises suffer from the shortage of working capital. And the limited opportunities for obtaining loans complain about $14.8 \%$ of small and $17.7 \%$ of medium enterprises. High rates $(67 \%$ of small and $65 \%$ of medium enterprises) are the main factor driving companies to abandon bank lending. The second most widespread reason is over claiming collateral ( $40 \%$ of small and $39 \%$ of medium enterprises) [20].

One of the options for solving the cost-resource problem is getting funding under international donor programs. Small and medium enterprises support programs such as the German-Ukrainian Fund, the European Bank for Reconstruction and Development, the European Investment Bank, the USAID, the European Fund for South-Eastern Europe and others.

Based on all the above results of the study, we will identify the potential strengths and weaknesses, as well as the opportunities and threats for the development of small business in Ukraine in the context of the deployment of the 4th Industrial Revolution, using the SWOT analysis methodology (Table 6).

\section{Table 6 - Potential internal strengths and weaknesses, opportunities and threats of small} business development in Ukraine (Created by authors)

\begin{tabular}{|c|c|}
\hline Potential internal strengths & Potential internal weaknesses \\
\hline $\begin{array}{l}\text { The capacity to respond quickly to market requirements and satisfy the demand for } \\
\text { goods and services } \\
\text { Differentiation and individualization of demand, meet the users' special needs. } \\
\text { Smaller start-up investment } \\
\text { Possibility to redeploy resources } \\
\text { Production flexibility that contributes to its rapid repurpose, substitution of the } \\
\text { model, production renewal } \\
\text { Work in segments/compartments, which for various reasons are not profitable for } \\
\text { large enterprises } \\
\text { Small batch production, unprofitable for large enterprises } \\
\text { A small control unit } \\
\text { Lower production costs } \\
\text { Specialization in the production of a limited range of products }\end{array}$ & $\begin{array}{l}\text { Insufficient qualifications of employees } \\
\text { Lack of production capacity } \\
\text { Liquidity problems } \\
\text { Lack of working capital } \\
\text { Outdated technologies } \\
\text { Problems with power supply } \\
\text { Insufficient commodities/materials } \\
\text { Insufficient financial resources } \\
\text { Lack of opportunity to attract investment } \\
\text { capital } \\
\text { Low level of innovative potential }\end{array}$ \\
\hline Potential external opportunities & Potential external threats \\
\hline $\begin{array}{l}\text { Creating new jobs } \\
\text { Creating an effective competitive environment } \\
\text { Filling the budget and stable economic development } \\
\text { Proximity to local markets } \\
\text { Experimenters for large firms } \\
\text { Serving new products created by large enterprises } \\
\text { State support and financing of the creation of regional and local investment and } \\
\text { innovation clusters involving small and medium enterprises in the basic types of } \\
\text { economic activities and priority sectors of the economy } \\
\text { Development of information and consulting support for investment and innovation } \\
\text { activity } \\
\text { Providing advisory support for creating your own business } \\
\text { Ability to receive funding through international donor programs for supporting small } \\
\text { and medium businesses } \\
\text { Expansion of the consumer sector } \\
\text { Saturation of the market by goods and services } \\
\text { Increasing export potential } \\
\text { Better use of local raw materials. }\end{array}$ & $\begin{array}{l}\text { Low demand } \\
\text { Unstable political situation } \\
\text { High tax rates } \\
\text { Burdensome tax administration } \\
\text { Inflation } \\
\text { High regulatory pressure } \\
\text { Corruption } \\
\text { Frequent changes in economic legislation } \\
\text { The war in the East of Ukraine } \\
\text { High level of competition } \\
\text { Low availability of loans } \\
\text { High loan rates } \\
\text { Governmental ineffectiveness } \\
\text { Burdensome currency regulation } \\
\text { Restriction of labour legislation }\end{array}$ \\
\hline
\end{tabular}


Most of the above opportunities are formed in the form of measures aimed at promoting the development of small and medium businesses, reflected in the Strategy for the Development of Small and Medium Business by 2020, which was approved by the CMU on May 24, 2017 [21]. The document envisages deregulation of small and medium businesses, facilitating access to finance, stimulating interest in entrepreneurship and innovation, and attracting small business entities to foreign trade activities. It is important to consistently implement this approved strategy in practice to overcome existing problems and achieve the goals set

Conclusions and directions of further research. The determined list of internal strengths and weaknesses, as well as external opportunities and threats of small business development, will allow us to formulate a list of main areas for stimulating and supporting small business in Ukraine. We believe that the most important measures of state policy is to promote the development of small business in the conditions of the fourth industrial revolution should be such as: reducing the number of documents required for business, simplifying tax administration and transforming the State fiscal service into a service for taxpayers, creating the only information resource for entrepreneurs and the transfer of administrative services to electronic mode, improvement of credit conditions. Also, the general economic reforms are important for small businesses as for any business, namely tax reform, deregulation, judicial reform (especially in terms of property rights protection), currency control simplification, optimization of customs procedures, creation of an effective mechanism for allocating resources allocated in support of small business development taking into account new challenges caused by the unfolding of the fourth industrial revolution.

Further studies must consider the specification of state support measures for small businesses in Ukraine and the implementation of educational programs, bringing them to the attention of the general public as probable future entrepreneurs.

1. Bartoš, P., Rahman, A., Horák, J., Jáčová, H. (2015), Education and Entrepreneurship in the SME Segment in Economic Transformation, Economics \& Sociology, Vol. 8, No 2, 2015, pp. 227-239. DOI: 10.14254/2071- 789X.2015/8-2/16 [in English].

2. Wioleta Samitowska (2011), Barriers to the Development of Entrepreneurship Demonstrated by Micro, Small and Medium Enterprises in Poland, Economics \& Sociology, Vol. 4, No 2, pp. 42-49. [in English].

3. Civelek, M., Ključnikov, A., Dobrovič, J., Hudáková, M. (2016). A model of measurement of the quality of business environment in SME segment. Journal of International Studies, 9(2), 90-102. DOI: 10.14254/2071-8330.2016/9-2/6. [in English].

4. Heorhiadi H. (2016) Suchasnyj stan pidpryiemnyts'koi aktyvnosti v Ukraini [The current state of entrepreneurial activity in Ukraine] Efektyvna ekonomika, 3. (n.d.). Retrived from http://www.economy.nayka.com.ua [in Ukrainian].

5. Melen' O.V., Abramova O.V. (2016) Male pidpryiemnytstvo v Ukraini: problemy ta mozhlyvist' efektyvnoho funktsionuvannia [Small business in Ukraine: problems and the possibility of effective functioning] Naukovyj visnyk Khersons'koho derzhavnoho universytetu. 16, 2, 61-63 [in Ukrainian].

6. Simkiv L.Ye., Pobigun S.A. (2015) Tendentsii rozvytku maloho pidpryiemnytstva v Ukraini v umovakh dysproportsijnosti ekonomichnoho zrostannia [Trends in the development of small business in Ukraine in conditions of disproportionate economic growth] Hlobal'ni ta natsional'ni problemy ekonomiky, 3, 560-564 [in Ukrainian].

7. Tabins'kyj V.A., Telyatnik V.M., Simon A.П. (2017) Problemy ta perspektyvy rozvytku maloho biznesu v Ukraini [Problems and prospects of small business development in Ukraine] Molodyj vchenyj, 3 (43), 848-851 [in Ukrainian].

8. Tymchenko O.I. (2015) Problemy ta perspektyvy rozvytku maloho pidpryiemnytstva v rehionakh Ukrainy [Problems and prospects of small business development in the regions of Ukraine] Efektyvna ekonomika, 6. (n.d.). Retrived from http://www.economy.nayka.com.ua [in Ukrainian].

9. Feschenko S.S. (2014) Suchasni problemy rozvytku pidpryiemnytstva v Ukraini [Modern problems of entrepreneurship development in Ukraine] Upravlinnia rozvytkom, 2, 13-16. (n.d.). Retrived from http://nbuv.gov.ua/UJRN/Uproz_2014_2_8 [in Ukrainian]

10. Apostoliuk O.Yu. (2016) Priorytety derzhavnoi finansovoi pidtrymky maloho biznesu v Ukraini [Priorities of state financial support of small business in Ukraine] Efektyvna ekonomika, 7. (n.d.). Retrived from http://www.economy.nayka.com.ua [in Ukrainian]

11. Varnalij Z.S., Vasiltsiv T. G., Pokrishka D.S. (2014) Priorytety vdoskonalennia derzhavnoi polityky roz vytku maloho pidpryiemnytstva $\vee$ Ukraini [Priorities for improving the state policy of development of small business in Ukraine] Stratehichni priorytety, 2, 49 - 54. [in Ukrainian].

12. Polischuk H.O. (2017) Derzhavna pidtrymka rozvytku maloho pidpryiemnytstva: vitchyznianyj ta zarubizhnyj dosvid [State 
support for small business development: domestic and foreign experience] Aktual'ni problemy derzhavnoho upravlinnia, 51, 1-9. (n.d.). Retrived from http://www.kbuapa.kharkov.ua/e-book/apdu/2017-1/doc/6/03.pdf. [in Ukrainian].

13. Lukashova L.V.(2017) Aktual'ni problemy upravlinnya gospodars'koyu diyal'nistyu sub'yektiv malogo pidpry’yemny'cztva [Actual problems of management of economic activity of small business entities] Zbirny”k naukovy'x pracz" «Problemy" sy' stemnogo pidxodu v ekonomici», 1 (57), 89 - 94. [in Ukrainian].

14. Piatnytska G.T., Hryhorenko O.M. , Naiduk V.S. (2018) Metody 'chni ta prakty’ chni pidxody’ do ocinyuvannya innovacijnogo potencialu maly'x pidpry'yemstv restorannogo gospodarstva [Methodical and practical approaches to the assessment of the innovative potential of small enterprises in the restaurant industry] Agrosvit, 4, 53-63. [in Ukrainian]

15. Klaus, Schwab. (2015). The Fourth Industrial Revolution. What It Means and How to Respond. Foreign Affairs, December 12, Retrived from https://www.foreignaffairs.com/articles/2015-12-12/fourth-industrial-revolution [in English].

16. Illjašenko S.M., Illiashenko, N.S. (2016) Perspektyvy i zahrozy četvertoji promyslovoji revoljuciji ta jix uraxuvannja pry vybori stratehij innovacijnoho zrostannja [Perspectives and threats of the fourth industrial revolution and their consideration in choosing innovative growth strategies.] Marketynh i menedžment innovacij, 1, 11-21. [in Ukrainian].

17. Diial'nist' sub'iektiv velykoho, seredn'oho, maloho ta mikropidpryiemnytstva, 2016: statystychnyj zbirnyk [Activities of subjects of large, medium, small and microenterprises, 2016: statistical collection] Derzhavna sluzhba statystyky Ukrainy. [in Ukrainian]

18. Doslidzhennia nastroiv maloho ta seredn'oho biznesu [Study of the mood of small and medium business] Spilka pidpryiemtsiv Ukrainy. (n.d.). Retrived from http://sup.org.ua/uploads/2017/11/599d8ac517bfde0088c3972bb486e058.pdf [in Ukrainian].

19. Analitychnyj zvit: natsional'nyj ta rehional'nyj vymiry «Schorichna otsinka dilovoho klimatu v Ukraini» za rezul'tatamy natsional'noho opytuvannia maloho ta seredn'oho biznesu: 2016 rik [Analytical report: National and regional dimension "Annual assessment of the business climate in Ukraine" according to the results of the national survey of small and medium enterprises: 2016] / Prohrama USAID «Liderstvo v ekonomichnomu vriaduvanni» (LEV), Instytut ekonomichnykh doslidzhen' ta politychnykh konsul'tatsij . (n.d.). Retrived from (http://lev.org.ua/abca.html). [in Ukrainian].

20. Opytuvannia pro umovy bankivs'koho kredytuvannia [Survey on the conditions of bank lending] / Natsional'nyj bank Ukrainy. (n.d.). Retrived from https://www.bank.gov.ua/control/uk/publish/category?cat_id=20231434 [in Ukrainian].

21. Stratehiia rozvytku maloho i seredn'oho pidpryiemnytstva v Ukraini na period do 2020 roku [Strategy for the development of small and medium enterprises in Ukraine up to 2020] / Kabinet Ministriv Ukrainy. (n.d.). Retrived from http://zakon2.rada.gov.ua/laws/show/504-2017-\%D1\%80\#n8 [in Ukrainian].

I. В. Федулова, д.е.н., профессор, Київський національний торговельно-економічний університет (Київ, Україна);

Г. Т. П'ятницька, д.е.н., професор, Київський національний торговельно-економічний університет (Київ, Україна);

Л. В. Лукашова, к.е.н., доцент, Київський національний торговельно-економічний університет (Київ, Україна).

Малий бізнес України: особливості та проблеми розвитку в умовах четвертої промислової революції

У статті визначено особливості та основні проблеми розвитку малого бізнесу в Україні з урахуванням змін у ринковому середовищі внаслідок розгортання четвертої промислової революиії, здійснено порівняння малого бізнесу з великим та середнім, описано тенденції розвитку малого бізнесу в порівнянні з великими та середнім в Україні та з малим бізнесом в інших країнах, визначено чинники, що впливають на формування цих тенденцій, оцінено рівень інноваційного потенціалу малих підприємств України за видами економічної діяльності, визначено потенційні внутрішні сильні та слабкі сторони, можливості та загрози розвитку малого бізнесу в Україні. В країнах Європейського Союзу, США та Японії малі та середні підприємства складають близько 50\% загальної кількості зайнятих, їх частка у ВВП складає більше 50\%. Для порівняння, додана вартість малого та середнього бізнесу в Україні в 2016 році складала 60,1\%. У той же час між Україною та країнами Європейського Союзу існує певна різниия у розподілі доданої вартості за розміром підприємств. Так, на мікропідприємствах ЄС виробляється понад 20\% доданої вартості, а на малих та середніх підприємствах близько 18\%. В Україні основна частина доданої вартості (43,4\%) формується середніми підприємствами. Малі підприємства формують 16,7\% доданої вартості, а мікропідприємства - лише 5,4\%, що свідчить про низьку ефрективність діяльності мікропідприємств в Україні. Проведене дослідження засвідчило, що чинниками, які негативно впливають на розвиток малого бізнесу в Україні, є: дуже низький попит на продукиію (59\% з 1800 респондентів), нестабільна політична ситуація (44\%); високі податки (35\%); складна система податкового адміністрування (27\%); інфрляція та часті зміни законодавства (26\%), високий регуляторний тиск та корупиія (23\%); війна на Сході країни (20\%); низька доступність кредитів (19\%). Брак ффінансування для розвитку бізнесу виявився актуальними для 44\% малих та середніх підприємств України, 33\% середніх та 36\% малих підприємств страждають від браку оборотних коштів. Встановлено також, що значна частина малих підприємств в Україні має низький рівень інноваційного потенціалу, що створює суттєві перешкоди для адаптації до трендів четвертої промислової революції.

Ключові слова: малі підприємства, малий та середній бізнес, підприємництво, внутрішні сильні та слабкі сторони розвитку, зовнішні можливості та загрози, інноваційний потенціал, четверта промислова революція, науково-технічний прогрес. 